\title{
Utilising Principles of Earth Jurisprudence to Prevent Environmental Harm: Applying a Case Study of Unconventional Hydraulic Fracturing for Shale Gas in the United Kingdom
}

\author{
Jack A. Lampkin ${ }^{1}$ D $\cdot$ Tanya Wyatt ${ }^{2}$
}

Published online: 21 January 2019

(C) The Author(s) 2019

\begin{abstract}
Approaching behaviour that produces environmental harm through the medium of criminal sanctions (largely involving monetary penalties) has been criticised consistently as failing to prevent environmental crimes and harms, and failing to concurrently reduce environmental re-offending. Furthermore, important state-corporate political and economic relationships exist that ensure the continuation of environmental degradation. We suggest that a way to overcome this is to re-work the current legal system to one grounded in Earth jurisprudence. Although we realise that state-corporate relationships would likely prevent the implementation of Earth jurisprudential principles, we argue such principles are essential to up-end the prioritisation of economic imperatives over ecological values within capitalist societies. To demonstrate the strength and utility of the Earth jurisprudential approach, we use the case of fracking for shale gas in the United Kingdom to examine how Earth jurisprudential principles could prevent environmental harm from occurring.
\end{abstract}

\section{Introduction}

The Earth's geology and ecosystems have been affected so drastically by human influences in the post-WWII era that many scientists and academics now agree that the reign of the Holocene geological epoch is ending and the age of the Anthropocene is beginning (Floyd 2015; Lewis and Maslin 2015; Shearing 2015; South 2015; Zalaseiwicz et al. 2010). There are a multitude of factors that have led to this state of affairs. First, large-scale disasters are having a profound impact on the surrounding land and coastal areas of such occurrences, such as the Gulf of Mexico and Valdez oil spills and the Chernobyl and Fukushima nuclear

Jack A. Lampkin

jlampkin@lincoln.ac.uk

Tanya Wyatt

tanya.wyatt@northumbria.ac.uk

1 Lincoln Law School, College of Social Science, University of Lincoln, Lincoln, UK

2 Department of Social Sciences, University of Northumbria at Newcastle, Newcastle-upon-Tyne, UK 
power-plant disasters. Second, the unprecedented exploitation and commodification of natural resources for use as consumer products and energy consumption (i.e., timber, oil, precious metals) continues to strip ecosystems of their fundamental natural resources, while at the same time, generating an unparalleled amount of non-biodegradable waste (i.e., electrical waste and plastics), as well as air, land, and water pollution. The rise and domination of the profit-seeking capitalist mode of production, twinned with remarkable technological innovation and an increasing human population, are the overwhelming driving forces behind this state of affairs. Third, the western, throwaway, disposable, capitalist consumer culture that fuels Schnaiberg's (1980) so-called treadmill of production means that most humans now contribute (often legally) to environmental harm 'en masse' (Halsey and White 1998: 347, emphasis in original). The amalgamation of these factors contributes to anthropogenic climate change in the form of global temperature rises, leading to sea-level rise, unpredictably extreme weather, and warmer, drier, harsher and more hostile climatic conditions. Such conditions will inevitably displace a large number of people who reside in the warmest regions, forcing environmental victims to seek refuge in more habitable climates (for critical thought on climate refugees, see, e.g., Brisman et al. 2018; Docherty and Giannini 2009; Hartmann 2010; Westra 2009).

Today's globalised capitalistic society places legal systems in an ecological-economic predicament. On the one hand, states are expected to provide for their people on a social level, collecting taxes to pay for healthcare, education, and various other amenities (for example, defence, transport, and law enforcement) that are deemed as essential components of modern human society. In addition, governments are tasked with implementing policies that facilitate economic growth, which is essential under capitalism in order to reduce poverty (Friedman 2002). In contrast, the state also has the function of making decisions pertaining to the environment, which also necessitate an ecological-economic cost. In the UK, environmental law is not a singular body of laws concerning the environment, but an amalgamation of several sources of law from various legal and policy instruments. Wolf and Stanley (2014: 5, emphasis in original) sum up the ecological-economic trade-off function succinctly when stating that:

Much of environmental law concerns the regulation of polluting emissions discharged into the three environmental media: air, water and land. The primary function of environmental law is not to eliminate pollution, except in the case of a relatively few highly toxic pollutants, but to balance the polluting emissions generated by economic activity against the demands of society for a tolerably healthy environment. Polluting emissions must therefore be set, in most cases, by governments (or its regulators) at levels which are acceptable to its two major stakeholders: regulated businesses and the public.

Violations of regulation resulting in criminal sanction does little to prevent offending or reduce reoffending for environmental crimes (Hall and Wyatt 2017; Lynch et al. 2016). For example, in 1999, Royal Caribbean Cruises Limited (RCC) incurred a fine of \$18 million for the deliberate dumping of pollutants (including waste oil and hazardous chemicals for dry cleaning, printing presses, and photo processing equipment) into United States coastal waters from its fleet of cruise ships (U.S. Department of Justice 1999). Despite this heavy fine (unprecedented for such an offence at the time), RCC still managed to increase their net income (profits) in 1999 to $\$ 383.9$ million, up 16\% from their 1998 net income (RCC 1999). Therefore, while a monetary fine can appear to be a successful outcome for an environmental crime offence, it may be unsuccessful in preventing recidivism, particularly where corporations are concerned. Despite this, financial penalties are by far the 
most common means for dealing with environmental crime offences (Billiet and Rousseau 2014), even though environmental offences have been found to be dealt with more leniently than comparable non-environmental crime offences (Cochran et al. 2016).

Therefore, it can be argued that, in order to prevent environmental degradation, a new approach needs to be adopted. Similar sentiments have been raised recently suggesting that a socio-legal approach, one that considers harm in addition to crime, is needed for environmental law to improve (Orlando and Bergen 2017). We seek to demonstrate that tweaking existing structures does not sufficiently ensure environmental protection. Rather we, like Wolf and Stanley quoted above, explore an approach where humans are not the main stakeholder. Instead, the environment is the main stakeholder. Clearly, this would contravene the traditional foundations of human-made law, which reflects human power struggles and human interest. An environmentally-centred approach to law-making with the environment (rather than humans) at the heart, would provide more legal protection for the Earth, its systems, and non-human animals. The newly developed field of Earth jurisprudence (EJ) is proceeding down this path. First, we will outline this theory and then we will use 'fracking' (unconventional hydraulic fracturing-UHF) as a case-study to show how an EJ approach would result in more eco-centred outcomes rather than economic ones.

\section{A Philosophy of Earth Jurisprudence}

Earth jurisprudence is an approach to legal decision-making that is very much in its infancy. In fact, the founder of Earth jurisprudential thought, Thomas Berry-the author of The Great Work - did not propose Earth jurisprudence until the very late twentieth century (Berry 1999). Since then, a small body of theoretical work on EJ has emerged within academic legal literature (see Koons 2008, 2009, 2010; Murray 2015), and there have been a small number of academic conferences specifically dedicated to issues of Wild Law and EJ (see, e.g., The Gaia Foundation 2018; University of Edinburgh 2016).

We have chosen to focus on the work of Cullinan (2011: 12-23), who provides a history of wild law and five succinct principles of EJ. This can be seen in the following commentary that has been adapted from Cullinan's (2011) work, and which will be applied to three risks surrounding UHF in the UK identified below (Table 1).

\section{Unconventional Hydraulic Fracturing (UHF) for Shale Gas in the UK: Creating Environmental Harm By Facilitating Production}

The political and economic uncertainty that followed the Second World War was mitigated somewhat in the UK by the discovery of North Sea oil and gas (Helm 2002). The ability to produce a domestic energy supply created a degree of security and removed some of the uncertainties surrounding importing fossil fuels during times of war. Such hydrocarbons were never going to be a successful long-term solution to energy creation or security, however, due to the non-renewable characteristics of fossil fuels. Hubbert's (1956) early theory of peak oil should have acted as a warning that building infrastructure, businesses, and services based on non-renewable resources could not be a long-term solution to the UK's energy demands.

Almost predictably, since the year 2000, North Sea oil and gas production have been in decline in the UK (Aleklett et al. 2010; Höök et al. 2010). As a result, the UK has seen a 
Table 1 Principles of Earth jurisprudence. Adapted from Cullinan (2011: 13)

\begin{tabular}{|c|c|}
\hline $\begin{array}{l}\text { Principles of } \\
\text { Earth jurispru- } \\
\text { dence }\end{array}$ & Description \\
\hline Principle one & 'The Universe is the primary law-giver, not human legal systems' (Cullinan 2011: 13) \\
\hline Principle two & $\begin{array}{l}\text { 'The Earth community and all the beings that constitute it have fundamental 'rights', } \\
\text { including the right to exist, to habitat or a place to be, and to participate in the evolu- } \\
\text { tion of the Earth community' (Cullinan 2011: 13) }\end{array}$ \\
\hline Principle three & $\begin{array}{l}\text { 'The rights of each being are limited by the rights of other beings to the extent necessary } \\
\text { to maintain the integrity, balance and health of the communities within which it exists' } \\
\text { (Cullinan 2011: 13) }\end{array}$ \\
\hline Principle four & $\begin{array}{l}\text { 'Human acts or laws that infringe these fundamental rights violate the fundamental } \\
\text { relationships and principles that constitute the Earth community ('the Great Jurispru- } \\
\text { dence') and are consequently illegitimate and 'unlawful' (Cullinan 2011: 13) }\end{array}$ \\
\hline Principle five & $\begin{array}{l}\text { 'Humans must adapt their legal systems, political, economic and social systems to be } \\
\text { consistent with the Great Jurisprudence and to guide humans to live in accordance } \\
\text { with it, which means that human governance systems at all times take account of the } \\
\text { interests of the whole Earth community and must: } \\
\text { determine the lawfulness of human conduct by whether or not it strengthens or weakens } \\
\text { the relationships that constitute the earth community; } \\
\text { maintain a dynamic balance between the rights of humans and those of other members } \\
\text { of the Earth community on the basis of what is best for earth as a whole; } \\
\text { promote restorative justice (which focuses on restoring damaged relationships) rather } \\
\text { than punishment (retribution); } \\
\text { recognise all members of the Earth community as subjects before the law, with the right } \\
\text { to the protection of the law and to an effective remedy for human acts that violate their } \\
\text { fundamental rights' (Cullinan } 2011: 13 \text { ) }\end{array}$ \\
\hline
\end{tabular}

rise in importations of oil and gas, and reductions in exports since the year 2004 (Bolton 2013).

Hubbert was also correct in terms of the future discoveries of fossil fuels, which have been aided by recent technological innovations. In the 1980s, Mitchell Energy, a company operating in the United States, succeeded in combining vertical with horizontal drilling techniques enabling the extraction of natural gas from previously inaccessible shale formations (Prud'homme 2014). This created what are now often classified as unconventional (horizontal) drilling techniques (Clough and Bell 2016), in unconventional (low-permeability) shale formations (Burgos et al. 2017), for unconventional hydrocarbons (shale gas) (Speight 2013).

While vertical hydraulic fracturing was a relatively well-known-but largely unprofitable-extraction technique (particularly in shale) conducted as early as the 1820 s in the United States (Prud'homme 2014) (and patented by Halliburton in 1949, see Montgomery and Smith 2010; Stretesky et al. 2014), the ability to drill and fracture horizontally enabled larger volumes of shale gas to be extracted per well (Norris et al. 2016) making unconventional (horizontal) drilling much more profitable than earlier conventional (purely vertical) techniques. While this technological innovation has clearly contributed significantly to the economic prowess of the United States (at least in fossil fuel terms), it has led to many instances of social (Hirsch et al. 2018), environmental (Hernandez 2018; Jackson et al. 2014), and non-human animal harms (Bamberger and Oswald 2015). This has resulted in the recent labelling of UHF as a form of extreme energy (Hulme and Short 2014; Short et al. 2015; Short and Szolucha 2017). 
Despite the socio-environmental issues associated with UHF in the United States, and the well integrity problems that occurred at the Preese Hall-1 well in Blackpool (UK) in $2011,{ }^{1}$ the UK government passed the Infrastructure Act 2015, which effectively legalised UHF in the UK following a temporary one-year moratorium on fracking implemented in 2011 (Hawkins 2015). This law has enabled oil and gas companies to apply for permits to conduct UHF onshore in the UK. As a result, the company Cuadrilla successfully completed drilling of the UK's first horizontal shale well (since Preese Hall) in April 2018 (Hayhurst 2018) at their Preston New Road site in Lancashire, ${ }^{2}$ making fracking in the UK imminent.

Our central argument is that an EJ approach to law-making, where the health and ecology of the earth is considered within decision-making, would lead to greater environmental protection and preservation. To this extent, UHF would not be permitted in the UK under such a philosophy. The following section will explain why.

\section{Three Major Environmental Risks Surrounding Fracking in the UK}

Academics in both the social sciences (e.g., Cotton 2017; Lampkin 2016, 2019; Short et al. 2015) and hard sciences (e.g., Jackson et al. 2014) have concluded that UHF in the UK poses several different risks to the environment. Before outlining three of these potential risks, it is important to note that they may not apply to all cases of UHF due to the UK's complex underlying geology (Loveless et al. 2018). This means different operators are likely to use a multitude of chemical additives and techniques in order to extract shale gas depending on the requirements of a site (Prud'homme 2014), resulting in different effects on the environment. Nevertheless, the development of fracking in the UK (based on research overseas) is likely to have negative outcomes with respect to: climate change, well integrity, and wastewater disposal. These issues will now be discussed in turn.

\section{Risk One: Negative Contribution to Climate Change}

A central argument of environmental concern regarding fracking is whether the process will aid in the UK's transition from non-renewable energy (coal, oil) to renewable energy. This has resulted in shale gas being described as a 'bridge fuel' (Cotton 2017: 186) to a 'low-carbon future' (Bomberg 2015: 83). '[W]hile it is true that less carbon dioxide is emitted per unit of energy released when burning natural gas compared to coal or oil' (Howarth 2014: 47), methane (the largest common constituent of shale gas) 'is a far more potent GHG than $\mathrm{CO} 2$, but... also has a tenfold shorter residence time in the atmosphere, so its effect on global warming attenuates more rapidly' (Howarth et al. 2011: 685). Therefore, the extent to which fracking will aid or inhibit the UK's ability to meet international climate agreements (such as Paris 2015) or the requirements of domestic legislation (such as the Climate Change Act 2008) is problematic. Furthermore, in the exploratory stages of UHF (pre-production), direct burning (also known as 'flaring') of natural gas is required

\footnotetext{
1 This was the first well to undergo onshore, horizontal, UHF in the UK and resulted in minor earthquakes and deformation of the well casing (see Green et al. (2012) for detailed information).

2 The UK government granted consent for Cuadrilla to conduct fracking for shale gas at this wellsite on 24 July 2018 (Department for Business, Energy and Industrial Strategy 2018).
} 
(Weinhold 2012). This is because the first gas to flow to the surface following initial drilling operations is unlikely to be accepted by the National Grid because of the 'dirty' constituents of the first gases that flow to the surface. These are likely to contain harmful contaminants that exist within the wellbore (such as naturally occurring radioactive materials (NORMs), Volatile Organic Compounds (VOCs) and other geological matter (Stamford and Azapagic 2014).

\section{Risk Two: Well Integrity Failure}

The integrity of fracking wells is paramount in ensuring chemicals (used to facilitate production), shale gas, and other geological matter (as described above) do not escape the well and contaminate the surrounding environment or escape into the atmosphere (Davies et al. 2014; Jackson 2014). This is important because wells are often drilled through shallow water aquifers and other groundwaters that exist below the Earth's surface in the UK. Aquifers provide an important source of consumable drinking water (up to $70 \%$ in some regions) (Southern Water 2018). Furthermore, it has been suggested that well integrity issues (i.e., the deterioration of wells) increase over time (Boothroyd et al. 2016), with some implying that the majority of all wells will fail 'by maturity' (Gottschalk et al. 2013: 9). This means that the long-term integrity and monitoring of wells is vital in order to ensure environmental protection. The UK, however, has no plan in place for the long-term, indefinite, management of onshore oil and gas wells. For example, Davies and colleagues (2014) found that the ownership of up to $53 \%$ of onshore conventional ${ }^{3}$ wells in the UK is not clear. This has obvious implications for the management of well integrity in the longterm and poses important questions of who is responsible for the restoration of wells if the environment (such as a water aquifer) is contaminated (Lampkin forthcoming). In the UK, it is clear that such responsibility will fall on the landowner if the ownership of a well is unclear and if there have not been any finances reserved for such circumstances (Department for Communities and Local Government 2014; Lampkin forthcoming), raising pertinent social justice issues.

\section{Risk Three: Wastewater Disposal}

The final aspect of environmental harm that could emanate from UHF operations in the UK is the difficulty in dealing with wastewaters. Wastewaters can be divided into two different types of water. The first, known as 'flow-back water', is the water that originally returns to the surface of the well in the immediate weeks following drilling (Speight 2013: 154). The second type, known as 'produced water', is water that continues to return to the surface of the well during extended oil and gas production (Speight 2013: 159). In the UK, wastewaters are classified as 'extractive waste' and are therefore regulated under the UK Mining Waste Directive (Royal Society and Royal Academy of Engineering 2012).

\footnotetext{
3 The conventional wells noted here are different from the unconventional wells discussed in this article. While an unconventional well utilises both vertical and then horizontal drilling techniques, a conventional well is limited to only vertical drilling. A further distinction can be made between the type of hydrocarbon targeted in the two well types. A conventional well traditionally targets a high-permeability geological formation (horizontal drilling is not required here because oil and gas is more easily extractable). Conversely, horizontal drilling targets less accessible, low-permeability formations (such as shale), where oil and gas does not flow as readily (and therefore needs to be induced with high-pressure and horizontal drilling techniques).
} 
Wastewaters cannot be released into freshwater systems (rivers, streams, canals, the sea) without being treated to reduce salinity (O'Donnell et al. 2018).

There are three main problems associated with the treatment of wastewaters. First, it is an expensive process (Hammer et al. 2012; O'Donnell et al. 2018), which means operators may attempt to find the cheapest method of disposal in order to ensure monetary profit. Second, produced water may be allowed by the Environmental Regulator (the Environment Agency (EA) to be re-introduced into a well (as a storage solution), which reduces the need for treatment. In the United States, the re-injection of wastewaters has been correlated directly with earthquakes (Ellsworth 2013; Estrada and Bhamidimarri 2016) and may also affect the integrity of wells (Folger and Tiemann 2016). Finally, the capacity for specialist wastewater treatment facilities in the UK to deal with fracking waste has been questioned (O'Donnell et al. 2018), due largely to the anticipated toxicity and salinity of fracking wastewaters. O'Donnell and colleagues (2018) found that there may be only four sites in the UK that hold the required specialist license to deal with contaminated wastewaters.

There are clearly significant risks to the environment that are permitted under the current legislative framework that regulates energy extraction. We will now examine what UHF in the UK would look like if the regulation governing it were grounded in EJ.

\section{Applying Cullinan's Work to the Three Identified Risks}

\section{Principle One}

The first principle denotes that the universe (rather than human legal systems) should be the primary law-giver (Cullinan 2011). The 'laws' of nature and of the universe, which are different to human-made laws, are created by chemical, cosmological and physical properties, enabling life to exist. Therefore, human actions should be confined to actions that do not disrupt the processes or properties that enable life to exist. Conversely, the history and development of human-made law (at least in a UK context) represent cultural, economic and social power struggles, dating back to the Magna Carta and attempts to constrict the powers of King John (Linebaugh 2008), and have largely taken no consideration of the processes and properties of nature.

UHF is an example of this because it is being permitted by the UK government despite the potential impact on climate change and the risks posed by well integrity and wastewaters. These possible risks interrupt the laws of nature by disrupting the carbon cycle. They do this by: contributing greenhouse gases that are linked to global warming; spreading lifethreatening contaminants when wells fail; and impairing the water cycle by contaminating water and using excessive amounts of it. In addition, British policies that have ended support for renewable energy technologies, like solar and wind, suggest that the humancentred or even corporation-centred British legislation not only ignores the laws of nature, but facilitates human demand for fossil fuel energy (and subsequent environmental harm). An EJ approach to legal decision-making regarding UHF would, in our eyes, not permit fracking due to the environmental harms that negatively affect the natural processes of our planet. 


\section{Principle Two}

The second principle suggests that all the beings that constitute the Earth community have a fundamental natural right to exist, to habitat 'and to participate in the evolution of the earth community' (Cullinan 2011: 11). The risks associated with UHF, climate change, and well integrity have particular weight here. Simply put, EJ would not permit UHF where significant research exists to suggest fracking will have a negative effect on climate change (Staddon and Depledge 2015). While some species can adapt and evolve to meet the demands of a changing environment, climate change is estimated to contribute to the extinction of one in six species worldwide, although it will likely happen most acutely in South America, Australia, and New Zealand (Urban 2015).

Furthermore, although wells are cased with multiple barrier systems that consist of steel and concrete casings (Jackson 2014) designed to contain chemicals and other substances within the well, full well integrity failure presents a pathway for contaminants to enter the natural environment (King and King 2013) and thereby hinder the 'fundamental rights' (Cullinan 2011: 13) of the organisms that exist within water aquifers and within the subsurface geology more generally. Therefore, an EJ approach to legislation would not permit UHF because of the risk of infringing the fundament rights of different beings within the Earth community.

\section{Principle Three}

The third principle is linked closely to the second principle. Principle Three provides: 'The rights of each being are limited by the rights of other beings to the extent necessary to maintain the integrity, balance and health of the communities within which it exists' (Cullinan 2011: 13). This principle speaks more to the relationship between beings/species than to an individual being's right to life. One species should not be allowed to engage in unnecessary actions (those not essential to health and/or survival), when the actions threaten other beings.

The potential consequences of UHF_climate change (Staddon and Depledge 2015), contaminated water supplies (Burgos et al. 2017; Gottschalk et al. 2013), earthquakes (Ellsworth 2013), loss of habitat due to the infrastructure required for wellpads, and noise ${ }^{4}$ - all likely impinge upon other species' individual and community health and wellbeing. The supposed need for humans to have fossil fuel energy does not supersede the right of other species to maintain the integrity and health of their populations. As such, legislation grounded in EJ would balance human needs (rather than desires) with the rest of the environment and other species. We suggest that this would lead to the prohibition of UHF and other environmentally destructive activities that prioritise human desires over other beings' health and survival.

\section{Principle Four}

Any actions that violate the principles would be made illegal under a system based on Earth jurisprudence. There would not be a system of regulation and oversight of environmentally destructive behaviour as currently exists in the UK and elsewhere. As it stands,

\footnotetext{
${ }^{4}$ The term wellpad refers to the 'area around a shale gas well where machinery is positioned' (Stephenson 2015: 148).
} 
the legislative and regulatory system sets limits on the amount of environmentally harmful activity that is allowed. For instance, in UHF, water companies delegate how much fresh water a fracking company can use instead of prohibiting the use of fresh water resources altogether. Similarly, the EA in the UK is responsible for regulating the type and quantity of chemical substances to be used in fracking operations (EA 2017), instead of prohibiting the use of chemicals altogether. Finally, while flaring (or otherwise burning) waste gases is an environmentally destructive waste disposal technique that can contribute negatively to climate change via the release of harmful GHG emissions (Jackson et al. 2014; Kadafa 2012: 44-45; Weinhold 2012), restricting the process of UHF through the application of EJ principles would act to restrict fracking on the basis that the health of the planet should be of greater importance than producing energy in environmentally destructive ways. This is because energy can be created in much less environmentally catastrophic ways (than fracking-such as through commitments to renewable energy).

\section{Principle Five}

Finally, these philosophical principles need to be put into action and to do so 'humans must adapt their legal, political, economic and social systems to be consistent with the Great Jurisprudence' (Cullinan 2011: 13). Furthermore, all governance systems that guide human activity must ensure that the whole Earth community is considered (Cullinan 2011). In establishing this radically different legal system, the whole Earth community's well-being would be a central focus (rather than only human interests) in order to protect the environment and the planet. The benchmark for legislation is whether human action strengthens or weakens the interconnectedness of the Earth community. In regards to UHF, we argue this would not be allowed as it contributes to the disruption of two core natural cycles-hydrological and carbon-in addition to negatively affecting environmental wellbeing where fracking takes place. This weakens numerous planetary relationships. Furthermore, legislation must ensure that there is a 'dynamic balance' between people and the environment and other beings based on what is best for the whole Earth community. This principle of creating new legislation ensures the notion that human desires are not at the centre of what actions are permissible. Quite the opposite, humans are not prioritised and their actions are curtailed if they are not in the interest of a holistic approach to planetary wellbeing. UHF serves no other purpose than to provide humans with (fossil fuel) energy. As energy can be obtained in other ways that have less or no impact on the environment, UHF is not permitted in an EJ legislative framework.

In instances where the environment is damaged (which would largely be a criminal violation), then, whenever possible, the relationship or the damage should be restored to its former state (Cullinan 2011). Cullinan (2011) refers to this as restorative justice. In traditional criminological literature, restorative justice refers to 'a method of responding to crime that includes the key parties to the dispute (that is, victim and offender) with the aim of repairing the harm' (Daly 2000: 1). Whereas this has some relevance to the restorative justice Cullinan suggests, in terms of the green criminological literature, this more closely aligns to White's (2017) notion of reparative justice. In reparative justice, the environmental offender must repair and take responsibility for the damage. 
The last element to a restructured legal system would be that all beings are subjects recognised by the law. Currently, non-human animals are regarded widely as property. Although efforts are being made to grant legal personhood status to non-human animals, particularly chimpanzees and elephants, in most parts of the world, this has not been successful (Wise 2014). Giving other beings recognition in the legal system would mean that activities, such as UHF, that harm other beings would not be allowed. Clearly, for other environmental harms, this final aspect of Principle Five of EJ has global ramifications for the agriculture, food and pharmaceutical industries among many others.

\section{Limitations to an Earth Jurisprudence Approach}

Such a radical change to society is, of course, fraught with obstacles, both political and practical. We suspect that states and corporations, in particular, would oppose such changes as they challenge several aspects of their existence. First, an Earth-centric society with a legal infrastructure protecting the whole Earth community would disrupt markets and industries as they currently function. Corporations would not want this to happen as it may impact (decrease) their profits. As Berry (1999: 118-119) suggests, corporations 'are especially resistant to any restraints on their activities based on protection of the environment.'

Similarly, states, often controlled by or colluding with corporations, would presumably encourage a human-centred legal system that supports human wants and needs (rather than an ecologically-centred legal system that prioritises the health of the planet) because the generation of profits by large corporations enables governments to achieve economic growth, which is deemed in modern capitalist society to be an 'intrinsic good' (Blauwhof 2012: 254). States are then unlikely to change the law in such drastic ways. This is evident by the UK's support of fracking, where the potential impact of the process on economic growth (Department for Business, Energy and Industrial Strategy 2017), energy security, and jobs (Institute of Directors 2013), takes precedence over ecological health. An alternative critical view, however, might contend that any 'economic development that causes environmental degradation makes a negative contribution to the creation of wealth' (Ruggiero and South 2013: 366) because natural resources are required for both consumption and fuel. As a result, it could be argued that the environmental harms associated with fracking (see, e.g., Jackson et al. 2014) are detrimental to economic development in the long-term.

Second, corporations and states would probably not agree to an Earth-centric society because at the core of this approach is a holistic inclusive attitude to governance and decisionmaking. This would mean the voices of women, minorities, and other species would all be given equal weight, thus diminishing the power of those running the current system, where white men and corporations tend to dominate and direct most societies. So, an EJ approach not only disrupts industries to foreground the environment but would also consist of more equal human societies.

In terms of practical obstacles to Earth jurisprudence, the question remains as to whether it is actually possible for laws to be free of human influence, when obviously they are drafted and created by humans. Are we able to switch from human-centred thinking that has mostly has been individualistic in nature to being concerned with our actions from the perspective that humans are one small part of a larger ecological community? As Rogers (2017: 2) questions:

How do we interpret or deconstruct our existing law/laws wildly, such that humanity is not necessarily the primary focus? How do we disregard our own self- interest, our ingrained assumptions and presuppositions as part of the human species, and indeed as 
part of a particular subset of the human species, to prioritise or at least recognise and respect Earth and its many communities and lifeforms in the process of wildly rewriting law?

While it may seem impossible, then, to rid laws of human influence, there are a few realworld examples which demonstrate that a shift to EJ may be possible. The Constitutions of Ecuador and Bolivia, for instance, recognise the rights of Mother Earth or the Pachamama (Humphreys 2017) and New Zealand has given legal personhood to the Whanganui River (Hutchinson 2014). These example indicate that there is the potential to overcome both the political and practical obstacles necessary to create an Earth-centred global society. The effectiveness of such change (in terms of preventing human-induced environmental harm through providing natural rights at state level) is still subject to debate, however. In the case of Ecuador, for example, Humphreys (2017: 476) suggests that 'the pro-economic growth bias of the modern state' has led to uncertainties around 'whether the state has the capability to uphold the rights of nature' due to the conflicting imperatives of protecting the environment and utilising the environment to obtain economic growth (for example, through transforming natural resources into consumable products to be sold by corporations).

These examples also supply a solid foundation on which to begin constructive dialogues as to how to bring about such changes. Exploring the implementation of, and then compliance with, constitutional protections and legal personhood for non-humans can provide pathways forward for similar protections to be enshrined in law in other places. Other avenues forward could be to undertake a project like the 'Feminist Judgments Project', where cases (we suggest laws as well) are written from alternative feminist judgments (Hunter et al. 2010). In this way, the flaws in legislation that fail to protect the environment and people from environmental harm would become evident and what Earth-centred law looks like in practice would be made clear. This, too, may offer a starting point for changing a legal system and a society to truly protect the planet.

\section{Conclusion}

It is clear that EJ provides a distinct philosophical approach to law-making with regards to interactions between the economy and the ecology. EJ is a perspective grounded in the cosmos whereby law-making exists to facilitate natural ecological processes, supporting and enabling life to flourish. Unlike Western legal systems today, EJ approaches to lawmaking refuse to regard human desires as morally superior. Instead, EJ places human wants and needs within the broader context of planet Earth, where humans are just one part of a complex ecological system.

We have acknowledged that an EJ approach to law-making has many difficulties in practice. The greatest of these challenges is perhaps the very nature of law itself, whereby the history of the function of law over the previous 800 years (in the UK, at least) has been to settle disputes and instil order between Homo sapiens. Arguably, such a long-standing human-centred jurisprudence has facilitated human domination of nature, enabling state-corporate relationships to flourish. As a result, implementing an Earth-centred jurisprudence through human-made law is undeniably problematic.

Despite such practical constraints regarding implementation, this article has shown that an EJ approach to law-making would be undeniably beneficial for non-human animals and the wider ecological health of planet Earth. At the time of writing, human domination of nature is immense and such power has resulted in devastating negative impacts for the 
environment. The recent state-corporate fascination with UHF in the UK is a fitting contemporary example of human prioritisation of desires (the production of fossil fuel energy) over the protection of the environment in modern capitalist societies.

We used three examples of how UHF in the UK could lead to serious environmental harms, which included implications for climate change, as well as the environmental concerns associated with full well integrity failure and wastewater disposal. We situated these arguments within the perspective of EJ (particularly drawing on the seminal work of Cormac Cullinan) to show how law-making from an EJ approach (that is, understanding the importance of the health of planet Earth) would lead to a ban on fracking in the UK due to the potential implications of the process on the environment. To reiterate a key example, UHF production requires flaring, emitting GHGs in the initial stages of the process, thereby contributing to climate change. This is not an accidental by-product of the process, but a known and essential component of UHF that demonstrates the complexities surrounding the process and the willingness of governments and companies to accept environmental harm in return for short-term economic gain.

To conclude, we propose that more needs to be done in the areas of law (and criminology) to understand how an EJ philosophy may be implemented in practice. Not only would such an approach be beneficial for the natural environment, but it would be undeniably helpful for the long-term survival of humans who ultimately rely on the natural environment in order to survive. As Wyatt (2013: 62) denotes when discussing anthropocentrism, it:

is so focused on short-term gain that the eventual damage to human livelihoods and health caused by overexploitation is not recognised or acknowledged. Human profits and well-being are threatened in direct contradiction to the aim of an anthropocentric approach, yet in not understanding the interconnectedness of people to the environment, destructive behaviours continue unquestioned.

\section{Compliance with Ethical Standards}

Conflict of interest The authors declare that they have no conflict of interest.

Open Access This article is distributed under the terms of the Creative Commons Attribution 4.0 International License (http://creativecommons.org/licenses/by/4.0/), which permits unrestricted use, distribution, and reproduction in any medium, provided you give appropriate credit to the original author(s) and the source, provide a link to the Creative Commons license, and indicate if changes were made.

\section{References}

Aleklett, K., Höök, M., Jakobsson, K., Lardelli, M., Snowden, S., \& Söderbergh, B. (2010). The peak of the oil age-analyzing the world oil production reference scenario in world energy outlook 2008. Energy Policy, 38(3), 1398-1414.

Bamberger, M., \& Oswald, R. E. (2015). Long-Term impacts of unconventional drilling operations on human and animal health. Journal of Environmental Science and Health, 50(5), 447-459.

Berry, T. (1999). The great work: Our way into the future. New York: Three Rivers Press.

Billiet, C. M., \& Rousseau, S. (2014). How real is the threat of imprisonment for environmental crime? European Journal of Law and Economics, 37(2), 183-198.

Blauwhof, F. B. (2012). Overcoming accumulation: Is a capitalist steady-state economy possible? Ecological Economics, 84(2012), 254-261. 
Bolton, P. (2013) Energy imports and exports. Produced For: House of Commons Library. Accessed June 14, 2018, from http://researchbriefings.files.parliament.uk/documents/SN04046/SN04046.pdf.

Bomberg, E. (2015). Shale we drill? Discourse dynamics in UK fracking debates. Journal of Environmental Policy \& Planning, 19(1), 72-88.

Boothroyd, I. M., Almond, S., Qassim, S. M., Worrall, F., \& Davies, R. J. (2016). Fugitive emissions of methane from abandoned, decommissioned oil and gas wells. Science of the Total Environment, 547, 461-469.

Brisman, A., South, N., \& Walters, R. (2018). Climate apartheid and environmental refugees. In K. Carrington, R. Hogg, J. Scott, \& M. Sozzo (Eds.), The Palgrave handbook of criminology and the global south (pp. 301-321). Cham: Palgrave Macmillan.

Burgos, W. D., Castillo-Meza, L., Tasker, T. L., Geeza, T. J., Drohan, P. J., Liu, X., et al. (2017). Watershedscale impacts from surface water disposal of oil and gas wastewater in Western Pennsylvania. Environmental Science and Technology, 51(15), 8851-8860.

Climate Change Act 2008 (c.27). London: TSO. Accessed July 26, 2018, from http://www.legislation.gov. uk/ukpga/2008/27/contents.

Clough, E., \& Bell, D. (2016). Just fracking: A distributive environmental justice analysis of unconventional gas development in Pennsylvania, USA. Environmental Research Letters, 11(2), 025001.

Cochran, J. C., Lynch, M. J., Toman, E. L., \& Shields, R. T. (2018). Court sentencing patterns for environmental crimes: Is there a "green" gap in punishment? Journal of Quantitative Criminology, 34(1), 37-66.

Cotton, M. (2017). Fair fracking? Ethics and environmental justice in United Kingdom shale gas policy and planning. Local Environment, 22(2), 185-202.

Cullinan, C. (2011). A history of wild law. In P. Burdon (Ed.), Exploring wild law: The philosophy of Earth jurisprudence (pp. 12-23). Mile End: Wakefield Press.

Daly, K. (2000). Restorative justice in diverse and unequal societies. Law Context: A Socio-Legal Journal, $17(1), 167190$.

Davies, R. J., Almond, S., Ward, R. S., Jackson, R. B., Adams, C., Worrall, F., et al. (2014). Oil and gas wells and their integrity: Implications for shale and unconventional resource exploitation. Marine and Petroleum Geology, 56, 239-254.

Department for Business, Energy and Industrial Strategy. (2017). Guidance on fracking: Developing shale gas in the UK. Accessed July 26, 2018, from https://www.gov.uk/government/publications/about-shale -gas-and-hydraulic-fracturing-fracking/developing-shale-oil-and-gas-in-the-uk.

Department for Business, Energy and Industrial Strategy. (2018). Decision announced on the hydraulic fracturing consent application by Cuadrilla Bowland Ltd: Response to Cuadrilla Bowland Ltd's application for hydraulic fracturing consent for its Preston new road site. Accessed July 26, 2018, from https://www.gov.uk/government/news/decision-announced-on-the-hydraulic-fracturing-consent-appli cation-by-cuadrilla-bowland-ltd?utm_source $=c 525 \mathrm{c} 083-993 \mathrm{c}-4 \mathrm{~b} 3 \mathrm{e}-\mathrm{adbb}-\mathrm{d} 3 \mathrm{e}$ 2c0726560\&utm_mediu $\mathrm{m}=$ email\&utm_campaign=govuk-notifications\&utm_content=immediate.

Department for Communities and Local Government. (2014). Guidance: Minerals. Accessed June 15, 2018, from https://www.gov.uk/guidance/minerals\#Restoration-and-aftercare-of-minerals.

Docherty, B., \& Giannini, T. (2009). Confronting a rising tide: A proposal for a convention on climate change refugees. Harvard Environmental Law Review, 33(2009), 349-403.

Ellsworth, W. L. (2013). Injection-induced earthquakes. Science, 341(6142), 1-7.

Environment Agency. (2017). Facts about fracking: Environmental controls in England. Accessed July 26, 2018, from https://consult.environment-agency.gov.uk/onshore-oil-and-gas/onshore-oil-and-gas-regul ation-information-page/user_uploads/2017-ea-environmental-controls-factsheet-2.pdf.

Estrada, J. M., \& Bhamidimarri, R. (2016). A review of the issues and treatment options for wastewater from shale gas extraction by hydraulic fracturing. Fuel, 182, 292-303.

Floyd, R. (2015). Environmental security and the case against re-thinking criminology as security-ology. Criminology \& Criminal Justice, 15(3), 277-282.

Folger, P. F., \& Tiemann, M. (2016). Human-induced earthquakes from deep-well injection: A brief overview. Congressional Research Service. Accessed June 15, 2018, from http://aquadoc.typepad.com/files /crs_human_induced_eqs.pdf.

Friedman, M. (2002). Capitalism and freedom: 40th Anniversary. Chicago: The University of Chicago Press.

Gaia Foundation. (2018). Talks and events. Accessed July 30, 2018, https://www.gaiafoundation.org/godeeper/events.

Gottschalk, K., Abdalla, C., Benham, B., Chambers, R., Howarth, R., Maloney, K., \& Wardrop, D. (2013) Exploring the environmental effects of shale gas development in the Chesapeake Bay Watershed. The 
Chesapeake Bay Program Scientific and Technical Committee. (Accessed June 15, 2018, from http:// www.chesapeake.org/pubs/297_Gottschalk2013.pdf.

Green, C. A., Styles, P., \& Baptie, B. (2012). Preese Hall shale gas fracturing: Review \& recommendations for induced seismic mitigation. Accessed July 30, 2018, from https://assets.publishing.service.gov.uk/ government/uploads/system/uploads/attachment_data/file/48330/5055-preese-hall-shale-gas-fracturing -review-and-recomm.pdf.

Hall, M., \& Wyatt, T. (2017). Capitalisation and gap analysis of environmental crime in the European Union. European Network for Prosecutors for the Environment.

Halsey, M., \& White, R. (1998). Crime, ecophilosophy and environmental harm. Theoretical Criminology, 2(3), 345-371.

Hammer, R., VanBriesen, J., \& Levine, L. (2012). In fracking's wake: New rules are needed to protect our health and environment from contaminated wastewater. Produced For: Natural Resources Defense Council. Accessed June 15, 2018, from http://www.oilandgasbmps.org/docs/GEN282-infrackings_ wake_nrdc.pdf.

Hartmann, B. (2010). Rethinking climate refugees and climate conflict: Rhetoric, reality and the politics of policy discourse. Journal of International Development: The Journal of the Development Studies Association, 22(2), 233-246.

Hawkins, J. (2015). Fracking: Minding the gaps. Environmental Law Review, 17(1), 8-21.

Hayhurst, R. (2018). UK's first horizontal shale gas well completed-Fracking due late summer. Produced For: Drill or Drop. Accessed June 15, 2018, from https://drillordrop.com/2018/04/03/uks-first-horiz ontal-shale-gas-well-completed-fracking-due-late-summer.

Helm, D. (2002). Energy policy: Security of supply, sustainability and competition. Energy Policy, 30(3), 173-184.

Hernandez, A. J. G. (2018). Shale gas extraction, energy reform, and environmental damage. In I. ArroyoQuiroz \& T. Wyatt (Eds.), Green crime in Mexico: A collection of case studies (pp. 39-48). London: Palgrave Macmillan.

Hirsch, J. K., Smalley, K. B., Selby-Nelson, E. M., Hamel-Lambert, J. M., Rosmann, M. R., Barnes, T. A., et al. (2018). Psychosocial impact of fracking: A review of the literature on the mental health consequences of hydraulic fracturing. International Journal of Mental Health and Addiction, 16(1), 1-15.

Höök, M., Bardi, U., Feng, L., \& Pang, X. (2010). Development of oil formation theories and their importance for peak Oil. Marine and Petroleum Geology, 27(9), 1995-2004.

Howarth, R. W. (2014). A bridge to nowhere: Methane emissions and the greenhouse gas footprint of natural gas. Energy Science \& Engineering, 2(2), 47-60.

Howarth, R. W., Santoro, R., \& Ingraffea, A. (2011). Methane and the greenhouse-gas footprint of natural gas from shale formations. Climatic Change, 106, 679-690.

Hubbert, M. K. (1956). Nuclear energy and the fossil fuels. Presented Before the Spring Meeting of the Southern District Division of Production American Petroleum Institute Plaza Hotel, San Antonio, Texas, March 7-8-9, 1956. Accessed June 14, 2018, from http://www.energycrisis.com/Hubbe rt/1956/1956.pdf.

Hulme, K., \& Short, D. (2014). Ecocide and the 'polluter pays' principle: The case of fracking. Environmental Scientist, 23(2014), 7-10.

Humphreys, D. (2017). Rights of Pachamama: The emergence of an Earth jurisprudence in the Americas. Journal of International Relations and Development, 20(3), 459-484.

Hunter, R., McGlynn, C., \& Rackley, E. (2010). Feminist judgments: An introduction. In R. Hunter, C. McGlynn, \& E. Rackley (Eds.), Feminist judgments from theory to practice (pp. 3-29). Oxford: Hart Publishing.

Hutchinson, A. (2014). The Whanganui river as a legal person. Alternative Law Journal, 39(3), 179-182.

Infrastructure Act 2015. (c.7). London: TSO. Accessed July 26, 2018, from http://www.legislation.gov.uk/ ukpga/2015/7/part/6/enacted.

Institute of Directors. (2013). Infrastructure for business: Getting shale gas working. Accessed July 26, 2018, from https://www.igasplc.com/media/3067/iod-getting-shale-gas-workingmain-report.pdf.

Jackson, R. B. (2014). The integrity of oil and gas wells. Proceedings of the National Academy of Sciences, 111(30), 10902-10903.

Jackson, R. B., Vengosh, A., Carey, J. W., Davies, R. J., Darrah, T. H., O'sullivan, F., et al. (2014). The environmental costs and benefits of fracking. Annual Review of Environment and Resources, 39, $327-362$.

Kadafa, A. A. (2012). Oil exploration and spillage in the Niger Delta of Nigeria. Civil and Environmental Research, 2(3), 38-51. 
King, G. E., \& King, D. E. (2013). Environmental risk arising from well-construction failure-Differences between barrier and well failure, and estimates of failure frequency across common well types, locations and well age. SPE Production \& Operations, 28(04), 323-344.

Koons, J. (2008). Earth jurisprudence: The future of law and the planet. The Young Lawyer, 12(9), 2.

Koons, J. (2009). What is Earth jurisprudence? Key principles to transform law for the health of the planet. Penn State Environmental Law Review, 18(1), 47-69.

Koons, J. (2010). Earth jurisprudence and the story of oil: Intergenerational justice for the post-petroleum period. University of San Francisco Law Review, 46, 93-138.

Lampkin, J. A. (2016). Green criminology and fracking in the UK: An application of utilitarian ethics. Papers from the British Criminology Conference, 16(2), 20-37.

Lampkin, J. A. (forthcoming). The uncertainty of community financial incentives for 'fracking': Pursuing ramifications for environmental justice. In: N. South \& A. Brisman (Eds.), Routledge international handbook of green criminology. Abingdon, Oxon, UK: Routledge.

Lewis, S. L., \& Maslin, M. A. (2015). Defining the Anthropocene. Nature, 519, 171-180.

Linebaugh, P. (2008). The magna carta manifesto: Liberties and commons for all. Oakland, CA: University of California Press.

Loveless, S. E., Bloomfield, J. P., Ward, R. S., Hart, A. J., Davey, I. R., \& Lewis, M. A. (2018). Characterising the vertical separation of shale-gas source rocks and aquifers across England and Wales (UK). Hydrogeology Journal. https://doi.org/10.1007/s10040-018-1737-y.

Lynch, M. J., Barrett, K. L., Stretesky, P. B., \& Long, M. A. (2016). The weak probability of punishment for environmental offenses and deterrence of environmental offenders: A discussion based on USEPA criminal cases, 1983-2013. Deviant Behavior, 37(10), 1095-1109.

Montgomery, C. T., \& Smith, M. B. (2010). History of an enduring technology. Journal of Petroleum Technology, 62(12), 26-33.

Murray, J. (2015). Earth jurisprudence, wild law, emergent law: The emerging field of ecology and lawpart 2. Liverpool Law Review, 36, 105-122.

Norris, J. Q., Turcotte, D. L., Moores, E. M., Brodsky, E. E., \& Rundle, J. B. (2016). Fracking in tight shales: What is it, what does it accomplish, and what are its consequences? Annual Review of Earth and Planetary Sciences, 44, 321-351.

O’Donnell, M. C., Gilfillan, S. M. V., Edlmann, K., \& McDermott, C. I. (2018). Wastewater from hydraulic fracturing in the UK: Assessing the viability and cost of management. Environmental Science: Water Research \& Technology, 4, 325-335. Accessed July 30, 2018, http://pubs.rsc.org/-/ content/articlehtml/2018/ew/c7ew00474e.

Orlando, E., \& Bergen, T. (2017). Forging a socio-legal approach to environmental harms. In T. Bergen \& E. Orlando (Eds.), Forging a socio-legal approach to environmental harms. Global perspectives (pp. 3-19). London: Routledge.

Prud'homme, A. (2014). Hydrofracking: What everyone needs to know. New York: Oxford University Press.

Rogers, N. (2017). Performance and pedagogy in the wild law judgment project. Legal Education Review, 27(1), 1-19.

Royal Caribbean Cruises Ltd. (1999). 1999 Annual report. Accessed February 10, 2018, http://media .corporate-ir.net/media_files/NYS/RCL/1999AR/index3.html.

Royal Society and Royal Academy of Engineering. (2012). Shale gas extraction in the UK: A review of hydraulic fracturing. Accessed June 15, 2018, from http://www.raeng.org.uk/publications/reports/ shale-gasextraction-in-the-uk.

Ruggiero, V., \& South, N. (2013). Green criminology and crimes of the economy: Theory, research and praxis. Critical Criminology, 21(3), 359-373.

Schnaiberg, A. (1980). The environment: From surplus to scarcity. New York: Oxford University Press.

Shearing, C. (2015). Criminology and the anthropocene. Criminology \& Criminal Justice, 15(3), 255-269.

Short, D., Elliot, J., Norder, K., Lloyd-Davies, E., \& Morley, J. (2015). Extreme energy, 'fracking' and human rights: A new field for human rights impact assessments? The International Journal of Human Rights, 19(6), 697-736.

Short, D., \& Szolucha, A. (2017). Fracking Lancashire: The planning process, social harm and collective trauma. Geoforum. Accessed June 15, 2018, from https://reader.elsevier.com/reader/sd/D36A8651C8 1D482DB9DDBEE7059193E983FE1588B16461F156C25EE7B31060DC17439CDA54E7AB5D 00680AA8E26EF49C.

South, N. (2015). Anticipating the anthropocene and greening criminology. Criminology \& Criminal Justice, 15(3), 270-276.

Southern Water (2018). Groundwater. Accessed June 15, 2018, from https://www.southernwater.co.uk/ groundwater.

Speight, J. G. (2013). Shale gas production processes. Oxford: Elsevier. 
Staddon, P., \& Depledge, M. (2015). Fracking cannot be reconciled with climate change mitigation policies. Environmental Science and Technology, 49(14), 8269-8270.

Stamford, L., \& Azapagic, A. (2014). Life cycle environmental impacts of UK shale gas. Applied Energy, $134,506-518$.

Stephenson, M. (2015) Shale gas and fracking: The science behind the controversy. Oxford: Elsevier.

Stretesky, P., Long, M. A., \& Lynch, M. J. (2014). The treadmill of crime: Political economy and green criminology. New York: Routledge.

United States Department of Justice. (1999). Royal Caribbean to pay record \$18 million criminal fine for dumping oil and hazardous chemicals, making false statements: Cruise line faces 21 felony counts in 6 different U.S. courts. Accessed February 10, 2018, from https://www.justice.gov/archive/opa/pr/1999/ July/316enr.htm.

University of Edinburgh. (2016). Events: Earth jurisprudence and wild law: establishing a natural contract between Earth and humanity. Accessed July 30, 2018, from http://www.law.ed.ac.uk/other_areas_of_ interest/events/all_events/earth_jurisprudence_and_wild_law_establishing_a_natural_contract_betwe en_earth_and_humanity.

Urban, M. (2015). Accelerating extinction risk from climate change. Science, 348(6234), 571-573.

Weinhold, B. (2012). The Future of fracking: New rules target air emissions for cleaner natural gas production. Environmental Health Perspectives, 120(7), a272-a279.

Westra, L. (2009). Environmental justice and the rights of ecological refugees. London: Routledge.

White, R. (2017). Reparative justice, environmental crime and penalties for the powerful. Crime, Law and Social Change, 67(2), 117-132.

Wise, S. (2014). Rattling the cage: Toward legal rights for animals. Boston: Da Capo Press.

Wolf, S., \& Stanley, N. (2014). Wolf and Stanley on environmental law (6th ed.). Abingdon: Routledge.

Wyatt, T. (2013). Wildlife trafficking: A deconstruction of the crime, the victims and the offenders. Basingstoke: Palgrave Macmillan.

Zalaseiwicz, J., Williams, M., Steffen, W., \& Crutzen, P. (2010). The new world of the anthropocene. Environmental Science and Technology, 44, 2228-2231.

Publisher's Note Springer Nature remains neutral with regard to jurisdictional claims in published maps and institutional affiliations. 